\title{
DIVERSIFICATION OF LAMB MEAT IMPORTS IN EU COUNTRIES AND ITS TRENDS
}

\section{Luiza Ochnio}

Warsaw University of Life Sciences, Institute of Economy and Finances, Department of Econometrics and Statistics, Warsaw, Poland

e-mail: luiza_ochnio@sggw.pl

ORCID: 0000-0001-8875-7945

\section{Tomasz Rokicki}

Warsaw University of Life Sciences, Institute of Economy and Finances, Department of Logistics, Warsaw, Poland

e-mail: tomasz_rokicki@sggw.pl

ORCID: 0000-0003-3356-2643

\section{Grzegorz Koszela}

Warsaw University of Life Sciences, Institute of Economy and Finances, Department of Econometrics and Statistics, Warsaw, Poland

e-mail: grzegorz_koszela@sggw.pl

ORCID: 0000-0003-4175-4450

\section{Bogdan Klepacki}

Warsaw University of Life Sciences, Institute of Economy and Finances, Department of Logistics, Warsaw, Poland

e-mail: bogdan_klepacki@sggw.pl

ORCID: 0000-0003-3483-7530

(C) 2019 Luiza Ochnio, Tomasz Rokicki, Grzegorz Koszela, Bogdan Klepacki

This is an open access article distributed under the Creative Commons Attribution-NonCommercial-NoDerivs license (http://creativecommons.org/licenses/by-nc-nd/3.0/)

DOI: 10.15611/eada.2019.4.07

JEL Classification: Q13, Q17, C10

\footnotetext{
Abstract: The paper attempts to compare European Union countries in terms of the dynamics of changes in the value of lamb meat imports in the period 2003-2017. The standard against which this comparison was made was the average value, which should be understood as the growth dynamics of the examined feature for all EU countries together. For this purpose, tools related to the so-called Grade Data Analysis, such as the index of the unlikeness of structures " $a r$ " (in this case a good tool to determine the direction of changes and the speed of these changes for all EU countries) and overrepresentation maps (used to visualise these changes and for their interpretation). Additionally, with the help of GDA methods, EU countries were divided into groups characterised by smaller, medium and higher dynamics of changes in lamb imports. It can be concluded that the most dynamic growth in imports of this type of meat is found among the newest EU member states. This may
} 
indicate a change in dietary preferences in these countries. It may also be related to greater accessibility to goods previously considered as luxury, greater awareness of so-called healthy foods and the improved standard of living of societies that have joined the European Union.

Keywords: sheep meat imports, dynamics of growth, lamb, Grade Data Analysis, overrepresentation maps.

\section{Introduction}

One-third of the protein consumed by humans is found in animal products [Herrero et al. 2009], and 75\% of agricultural land is allocated to this production [Foley et al. 2011]. In the period 1961-2011, global meat production increased four to five times. The significance of Europe, which in 1961 accounted for $42 \%$ of the world's meat production and in 2011 for only 19\%, has diminished. There were also changes in the structure of meat produced by types. For example, the share of poultry increased from $12 \%$ to $35 \%$, beef decreased from $44 \%$ to $22 \%$, and pork remained unchanged [Ritchie, Rosner 2018]. According to the forecasts, the demand for meat and dairy products will increase by $60 \%$ by 2050 [Alexandratos, Bruinsma 2012]. In the European Union (EU), pork represents around 50\% of the total meat production and mutton only $2 \%$ [Meat... 2018].

The sheep and lamb meat market is regulated by the Common Agricultural Policy (CAP). It includes lamb (up to one year old), live sheep, fresh, chilled or frozen sheep meat, mutton meat, brine (dried or smoked, bone and boneless), edible sheep offal (fresh and frozen), mutton fat, preserved mutton meat and offal. The market for sheep meat in the EU is quite specific, because despite low levels of consumption, the production of lamb does not cover the reported demand. In 2007-2013 , there was a decline in both the production and consumption of this type of meat. The level of subsidyincreased, however it accounted for less than 90\%. There was constant demand for lamb meat on the market and imports were necessary, including mainly frozen meat from outside the EU [Rokicki, Ratajczak 2018]. The decrease in sheep meat production was not compensated by an increase in imports; therefore, the consumption of lamb decreased. In 2005, around $2.9 \mathrm{~kg}$ of this meat were consumed in EU countries per person, and in 2017 about $1.9 \mathrm{~kg}$. The main sources of lamb meat imports to the EU have remained unchanged for years. The largest percentage on the EU market was supplied by New Zealand (82\%-89\% of total imports in 2007-2016), followed by Australia (6\%-11\%) and South America, including Chile (1\%-2\%), Uruguay (0.6\%-1.7\%) and Argentina (0.3\%-1\%). For most countries, the volume of supplies has decreased. For the import of lamb meat, the Community tariff quotas were set. By 2011, the quotas were set annually and, since 2012, multiannual quotas have been in force, which for the majority of countries remain underutilised. Most countries imported frozen meat, but there were also imports of live animals from countries neighbouring the EU. Despite the 
shortage on the market, there were exports of lamb meat to Asian and African countries, but the volume was small and volatile [Rokicki 2017].

According to the forecasts of the EU Agricultural Perspectives Report 2017-2030, a slight increase in the production and consumption of lamb meat is expected by 2030 . This is due to improved profitability and the use of voluntary support for farmers in some EU countries [EU Agricultural... 2017].

The aim of the study was to to compare European Union countries in terms of the dynamics of changes in the value of lamb meat imports in 2003-2017. This is supposed to be connected with the change in dietary preferences in some countries and the awareness of healthy foods, but also with the possibility of buying more expensive food products. On the other hand there may be cultural or economic reasons for the increase or decrease in lamb meat consumption. The research results can help to predict the production trend of this type of meat and determine the markets.

\section{Material and methods}

The aim of the paper is to compare the pace of changes of lamb meat imports in European Union countries, in order to verify the assumptions about the changes that have taken place in the lamb market in recent years, in particular when it comes to the identification of potential new outlet markets. One of the approaches to determine the pace of change is the creation of ranking and grouping profiles of import volume structures in time periods for individual countries. The paper hypothesises that the largest increase in lamb meat imports should occur in newly acceded countries, where food preferences have undergone the strongest changes, partially replacing foods considered as traditional with products previously difficult to access, of better quality and previously reserved for more affluent societies.

The survey was conducted on data collected from 28 EU countries on 31 December 2017. Data refer to the period 2003-2017 and comes from the UN Comtrade Database, a repository of official international trade statistics and relevant analytical tables (www.comtrade.un.org). Due to the need to authenticate the obtained results, the examined 15-year period has been divided into five 3-year periods, where the data are the sum of the three years included in a given subperiod. The research used Grade Data Analysis (GAD) methods, which may be useful in analysing the dynamics of the phenomena in question.

A numerical example is used to support this thesis. Table 1 shows the quantities of lamb imports in thousands (euro) in five time periods $\left(y_{t}\right.$ for $\left.t=1, \ldots, 5\right)$ for three hypothetical countries. In Table 2 , the chain index values $i_{t / t-1}$ (quotients of values from a given period to values from a previous period $\left.y_{t} / y_{t-1}\right)$ and the value of the average rate of change index $i_{G}$ are given: 
Table 1. Lamb imports for five time periods

\begin{tabular}{|c|c|c|c|c|c|c|}
\hline & $y_{1}$ & $y_{2}$ & $y_{3}$ & $y_{4}$ & $y_{5}$ & Total \\
\hline Country_1 & $€ 350,000$ & $€ 402,500$ & $€ 442,750$ & $€ 531,300$ & $€ 584,430$ & $€ 2,310,980$ \\
\hline Country_2 & $€ 1,200,000$ & $€ 1,320,000$ & $€ 1,452,000$ & $€ 1,669,800$ & $€ 2,003,760$ & $€ 7,645,560$ \\
\hline Country_3 & $€ 70,000$ & $€ 77,000$ & $€ 92,400$ & $€ 101,640$ & $€ 116,886$ & $€ 457,926$ \\
\hline Total & $€ 1,620,000$ & $€ 1,799,500$ & $€ 1,987,150$ & $€ 2,302,740$ & $€ 2,705,076$ & $€ 10,414,466$ \\
\hline
\end{tabular}

Source: own calculations.

Table 2. Chain index values

\begin{tabular}{|l|c|c|c|c|c|}
\cline { 2 - 6 } \multicolumn{1}{c|}{} & $i_{2 / 1}$ & $i_{3 / 2}$ & $i_{4 / 3}$ & $i_{5 / 4}$ & $i_{G}$ \\
\hline Country_1 & 1.15 & 1.10 & 1.20 & 1.10 & 1.14 \\
\hline Country_2 & 1.10 & 1.10 & 1.15 & 1.20 & 1.14 \\
\hline Country_3 & 1.10 & 1.20 & 1.10 & 1.15 & 1.14 \\
\hline
\end{tabular}

where: $i_{G}=\sqrt[n-1]{\prod_{t=2}^{5} i_{t / t-1}}$.

Source: own calculations.

Table 2 shows that the index of the average rate of change for each country in the analysed period was the same and amounted to 1.14 . If one would like to examine the dynamics (the growth rate in this case) using this measure, a problem would arise in differentiating the speed of this pace. The methods associated with Grade Data Analysis may be very helpful here. Later on in the paper, the import value structures of particular countries will be compared with the import structures of the European Union for 3-year time periods. Thus it is worth mentioning the problems related to the measurement of the unlikeness of these structures. As for the measure of the unlikeness of structures in literature, many proposals can be found, among them the 'Minkowski measure', which is very popular. It meets two conditions [Vepstas 2008; Toth 2015]:

1. The distance (unlikeness) between objects with the same structure is equal to "0".

2. The distance (unlikeness) between a certain object $Y$ and an object $X$ is the same as between $X$ and $Y$ and is not less than " 0 ".

It is doubtful, however, whether the third condition for structures is correct:

3. The distance measures changes in accordance with the "transfer sensitivity" adopted in, for example, concentration indicators, where the increase of the value of the unlikeness index at a fixed transfer rate is higher, the "richer" the object to which the transfer was made [Toth 2015].

In the case of this study, it is a question of shifting the value of imports between particular 3-year time periods (shifting the same amount by a further 
period of time increases the value of the unlikeness index). This approach would fit more diversified countries in terms of the rate of change of lamb import value than in the case of measures considered to be cannonical (e.g. average growth rate).

The construction of the unlikeness of structures index which meets condition 3 can then be based on, for example, the Gini coefficient (G). The Gini coefficient [Atkinson 1970; Gastwirth 1972] is the doubled area between the diagonal of the square representing the egalitarian distribution and the Lorentz curve (see Figure 1a). It is defined by the following formula (formula 1a):

$$
G=1-2 \cdot \int_{0}^{1} f(t) d t
$$

By analogy with the Lorentz curve, the unlikeness of a certain $Y$ structure to a certain $X$ structure can be presented as a broken curve connecting certain points. These points have coordinates that are consecutive cumulative structures. For example, when comparing the values of lamb import structures for the Czech Republic and the European Union (see Table 3), the curve is shown in Figure 1b.

Table 3. Cumulative structures for the Czech Republic and the EU in time intervals

\begin{tabular}{|c|c|c|c|c|c|c|}
\cline { 2 - 7 } \multicolumn{1}{c|}{} & \multicolumn{3}{c|}{ EU } & \multicolumn{3}{c|}{ CZ } \\
\hline Period & value & $\%$ & $\%$ cum. & value & $\%$ & \% cum. \\
\hline $2003-2005$ & $5,200,276$ & 18.06 & 18.06 & 4,328 & 12.52 & 12.52 \\
\hline $2006-2008$ & $5,540,890$ & 19.25 & 37.31 & 5,605 & 16.22 & 28.74 \\
\hline $2009-2011$ & $5,938,165$ & 20.63 & 57.94 & 6,925 & 20.04 & 48.78 \\
\hline $2012-2014$ & $5,857,917$ & 20.35 & 78.28 & 7,989 & 23.12 & 71.90 \\
\hline $2015-2017$ & $6,252,222$ & 21.72 & 100.00 & 9,713 & 28.10 & 100.00 \\
\hline
\end{tabular}

Source: own calculations.
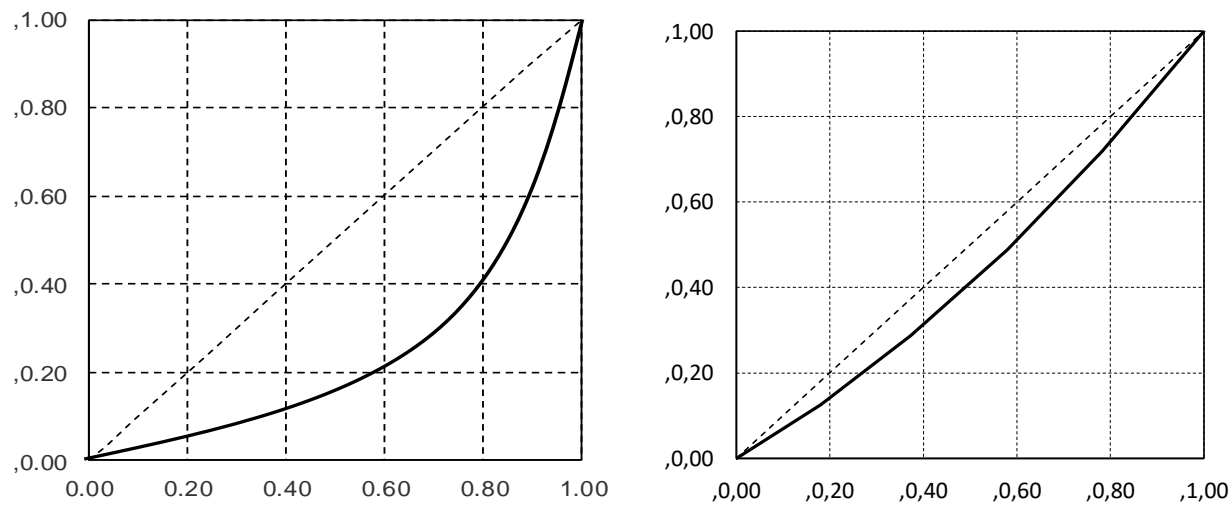

Fig. 1a. An example of Lorentz curve illustrative drawing

Source: own calculations.
Fig. 1b. Broken curve of lamb import unlikeness for the Czech Republic and EU countries

Source: own calculations. 
Table 4. Sample values of import dynamics changes

\begin{tabular}{|c|l|l|}
\hline ar & Total & \\
\hline Country_1 & 0.00016 & Description \\
\hline Country_2 & -0.00005 & Growth dynamics is lower than mean growth \\
\hline Country_3 & 0.00011 & Growth dynamics is higher than mean growth but lower than in Country_1 \\
\hline
\end{tabular}

Source: own calculations.

The measure of the unlikeness of structure $Y(\mathrm{CZ})$ to structure $X(\mathrm{EU})$, also on the basis of analogy, this time with the Gini coefficient, is the "ar" measure (formula 1b).

$$
\operatorname{ar}(\mathbf{y}: \mathbf{x})=\operatorname{ar}\left(\mathrm{C}_{[\mathbf{y}: \mathbf{x}]}\right)=1-2 \int_{0}^{1} \mathrm{C}_{[\mathbf{y}: \mathbf{x}]}(t) d t .
$$

In this case, the unlikeness of import value structures for individual time periods for the European Union (EU) and the Czech Republic (CZ) amounted to: $|\operatorname{ar}(\mathrm{CZ}: \mathrm{EU})|=0.119$. If one replaces the ar module with the ar itself, then besides information about the magnitude of unlikeness, one will also obtain information about its direction, that is: because $\operatorname{ar}(\mathrm{CZ}: \mathrm{EU})=0.119$ then $\operatorname{ar}(\mathrm{EU}: \mathrm{CZ})=-0.119$. In a similar way, one can determine the unlikeness of temporal structures for the theoretical example shown in Table 4, giving information on which countries "gain" and which "lose" when it comes to the growth rate of lamb imports in comparison to the total.

\section{Research results and discussion}

On the basis of the designated ar measures, it can be easy to refer to the concept of creating country rankings in terms of the dynamics of changes in the value of lamb imports in the period 2003-2017. Designating the structure for the European Union as the average structure for the whole population over a 15-year period (divided into five 3-year periods), the measure of the unlikeness of the structures in individual countries to the corresponding structures of the European Union can be set.

In order to treat this ranking as a determinant of which countries "gain" and which "lose" in the rate of changes of the import values in this sector, ar in module can be abandoned in favour of ar itself. This could allow for the presentation of the direction of changes, showcasing those countries which, over time, have seen an increase in the rate of lamb imports in relation to the entire Union (see Figure 2). 


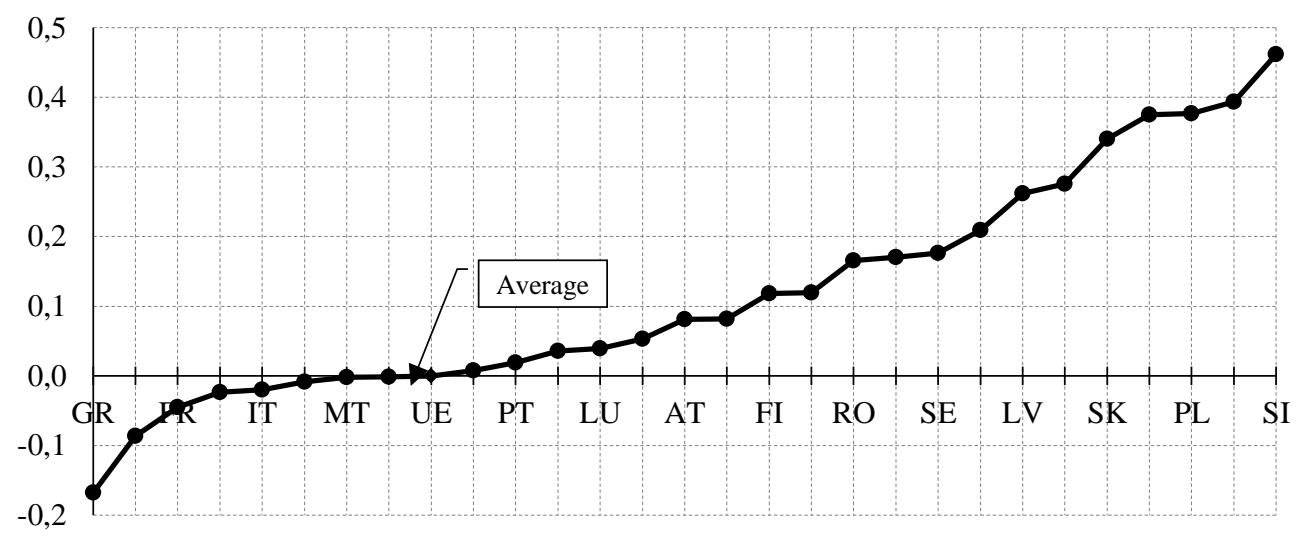

Fig. 2. Ranking of EU countries according to the ratio of changes in the growth rate of lamb imports in relation to the average value for EU countries

Source: own calculations.

Countries such as Greece, Belgium and France show a lower rate of change in imports of this type of meat than other EU countries. Conversely, the highest increase in lamb imports in the analysed years can be observed in newly acceded countries (i.e. LV, EE, SK, BG, PL, LT and SI).

In addition to indicators of structure unlikeness (time structures in this case), it is possible to build the so-called overrepresentation maps (a GDA tool). Prior to presenting the overrepresentation map for all EU countries, three case studies (GR, $\mathrm{CZ}$ and PL) will be used to illustrate the changes that have occurred in the time structures of lamb import values in comparison to the mean value. The import values (in thousands of euros) for these countries in the five analysed periods are presented in Table 5.

Table 5. Import values in thousands (euro) in 3-year periods for selected EU countries

\begin{tabular}{|l|c|c|c|c|c|r|}
\hline Country & $2003-2005$ & $2006-2008$ & $2009-2011$ & $2012-2014$ & $2015-2017$ & \multicolumn{1}{c|}{ Total } \\
\hline GR & 150.747 & 143.003 & 117.281 & 78.070 & 86.826 & 575.927 \\
\hline CZ & 4.328 & 5.605 & 6.925 & 7.989 & 9.713 & 34.560 \\
\hline PL & 1.766 & 3.260 & 8.731 & 15.434 & 21.499 & 50.690 \\
\hline Total & 156.841 & 151.868 & 132.937 & 101.493 & 118.038 & 661.177 \\
\hline
\end{tabular}

Source: own calculations.

The time structure for the value of lamb imports in Greece, the Czech Republic and Poland and their average structure are shown in Table 6. 
Table 6. The time structure for the value of lamb imports in selected EU countries

\begin{tabular}{|l|c|c|c|c|c|c|}
\hline Country & $2003-2005$ & $2006-2008$ & $2009-2011$ & $2012-2014$ & $2015-2017$ & Total \\
\hline GR & 0.2617 & 0.2483 & 0.2036 & 0.1356 & 0.1508 & 0.8711 \\
\hline CZ & 0.1252 & 0.1622 & 0.2004 & 0.2312 & 0.2810 & 0.0523 \\
\hline PL & 0.0348 & 0.0643 & 0.1722 & 0.3045 & 0.4241 & 0.0767 \\
\hline Average & 0.2372 & 0.2297 & 0.2011 & 0.1535 & 0.1785 & 1 \\
\hline
\end{tabular}

Source: own calculations.

Upon determining the structures and their average values, the "overrepresentation rates" can be calculated as a quotient of time structures for individual countries (see Table 7).

Table 7. Overrepresentation rates for selected EU countries in five time periods

\begin{tabular}{|l|c|c|c|c|c|}
\hline Country & $2003-2005$ & $2006-2008$ & $2009-2011$ & $2012-2014$ & $2015-2017$ \\
\hline GR & 1.1034 & 1.0810 & 1.0128 & 0.8831 & 0.8445 \\
\hline CZ & 0.5279 & 0.7061 & 0.9966 & 1.5059 & 1.5743 \\
\hline PL & 0.1469 & 0.2800 & 0.8567 & 1.9835 & 2.3757 \\
\hline
\end{tabular}

Source: own calculations.

Ideally, the representation index will be equal to 1, Determined "overrepresentation rates" allow for the drawing of an "overrepresentation map" (see Figure 3). In addition to the diagram, measures of the unlikeness ar are presented for selected countries in the given time structures, and the structures' unlikeness of these countries to the average structure.

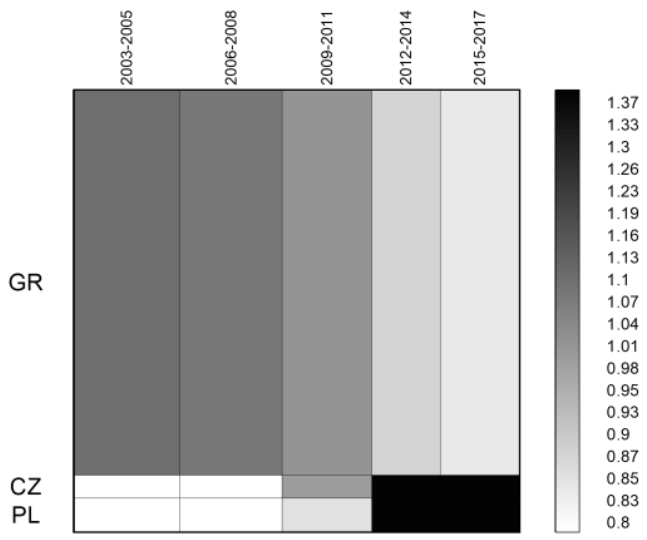

\begin{tabular}{|c|c|c|c|c|}
\hline$a r$ & GR & CZ & PL & Average \\
\hline GR & 0 & 0.0710 & 0.1324 & 0.0139 \\
\hline CZ & -0.0710 & 0 & 0.0652 & -0.0569 \\
\hline PL & -0.1324 & -0.0652 & 0 & -0.1188 \\
\hline Average & -0.0139 & 0.0569 & 0.1188 & 0 \\
\hline
\end{tabular}

Fig. 3. An "overrepresentation map" of the value of lamb imports for selected countries of the EU and the values of the measure of unlikeness $a r$

Source: own calculations. 
Similarly to the example for these 3 countries, the dynamics of the increase/decrease in the value of lamb meat imports for all EU countries in comparison with the average value is presented in Figure 4.

An "overrepresentation map" is a square with sides equal to 1 , in which the rows are occupied (in this case) by three countries, and the columns by five 3-year periods from 2003 to 2017. Shades of gray on the map show overrepresentation (grading to black) or underrepresentation (grading to white) in relation to the average. In the case of the method used to determine the average, the map has rows of different heights. The height is determined by the percentage share of the import value for each country against the value of total imports. The column widths are the average import structures for individual 3-year periods for Greece, the Czech Republic and Poland in total.

Figure 3 shows that the rate of change in the import of lamb was lower than the average for Greece (shades from dark to light). In the case of the Czech Republic and Poland, the tendency was reversed (from light to dark). By analogy, the dynamics of the increase/decrease of the value of lamb meat imports for all EU countries in comparison to the average value are presented in Figure 4.

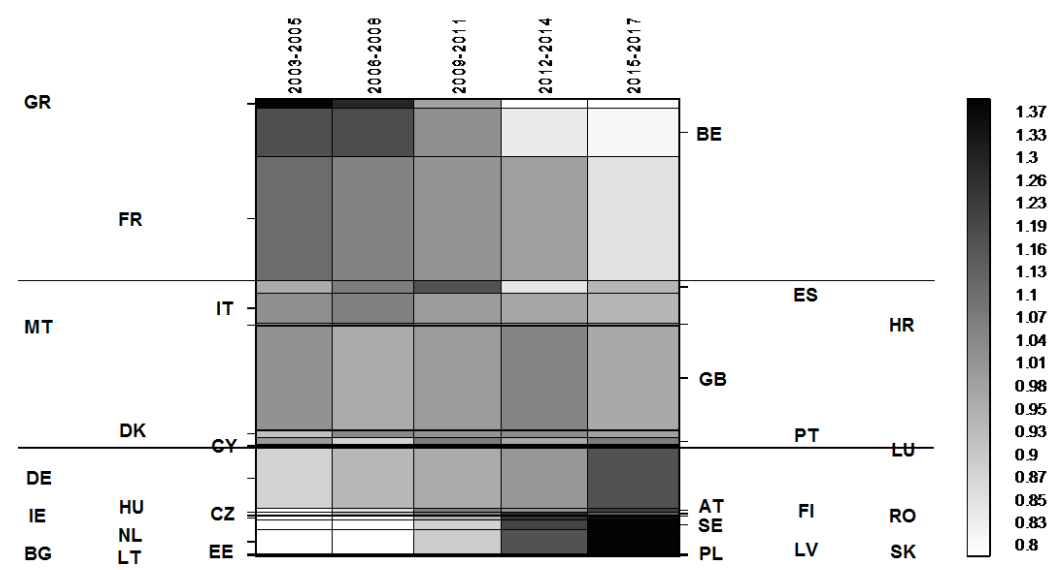

Fig. 4. "Overrepresentation map" of lamb meat import values in EU countries in 2003-2017

Source: own calculations.

The order in which rows from Figure 4 are arranged, the widths of which are the structure of lamb import values for individual countries (in the 15-year period under survey) against the value of imports for the entire EU, is not a coincidence. As part of the Grade Analysis of Data, the aim was to arrange the data matrix in such a way so as to achieve the maximum contrast between the extreme rows and columns visible on the "map". A special GCA (Grade Correspondence Analysis) algorithm that maximises a certain dependency ratio is used for this purpose. The correlation coefficient of 
Tau-Kendall $\tau(\boldsymbol{P})$ or rho-Spearman $\rho^{*}(\boldsymbol{P})$ is used as an index of dependence in this case. These indicators can be expressed as the measure of line diversity.

Let us take the " $P$ " data matrix, where elements " $p_{i j}$ " are not negative and add up to 1 .

Let " $p_{i+}$ " be the sums in rows " $i=1 \ldots . . . m$ " and " $p_{+j}$ " the sums in columns " $j=1 \ldots . . n$ " for this matrix.

Let " $\operatorname{ar}(t: s)$ " mean the value of the vectors differentiation index:

$$
\left(\frac{p_{t 1}}{p_{t+}}, \frac{p_{t 2}}{p_{t+}}, \ldots, \frac{p_{t n}}{p_{t+}}\right) \text { and }\left(\frac{p_{s 1}}{p_{s+}}, \frac{p_{s 2}}{p_{s+}}, \ldots, \frac{p_{s n}}{p_{s+}}\right) \text {. }
$$

Let $S_{i}^{*}=\frac{S_{i}+S_{i-1}}{2}$ for $S_{i}=p_{1+}+\ldots+p_{i+}, \quad i=1, \ldots, m$.

Then

$$
\begin{gathered}
\tau(\boldsymbol{P})=2 \cdot \sum_{t=2}^{m} \sum_{s=1}^{t-1}\left[\left(p_{t+} \cdot p_{s+}\right) \cdot \operatorname{ar}(t: s)\right] . \\
\rho^{*}(\boldsymbol{P})=6 \cdot \sum_{t=2}^{m} \sum_{s=1}^{t-1}\left[\left(S_{t}^{*}-S_{s}^{*}\right) \cdot\left(p_{t+} \cdot p_{s+}\right) \cdot \operatorname{ar}(t: s)\right] .
\end{gathered}
$$

For the optimal row order obtained by this method and presented in Figure 3, the values of these indicators are as follows: $\tau(\boldsymbol{P})=0.07991$ and $\rho^{*}(\boldsymbol{P})=0.11933$.

Clusters can also be built on the basis of these above mentioned indicators. Clusters are built to maximise the diversity between them. Diversity between two clusters is understood here as the difference between the two objects formed by these clusters as the sum of the objects included in each cluster. For the purposes of this study. three such aggregations were distinguished, shown in Figure 4, where two horizontal lines distinguish three groups of EU countries. In the first group, there are countries in which the growth rate of lamb imports was significantly lower than the EU average (according to the measure of the average index of change rates it even decreased, which signifies a change from strong overrepresentation to underrepresentation). The second group was only slightly different from the growth rate trends across the whole of the EU, while the third group was characterised by a shift from under-representation to overrepresentation during the relevant period. Countries in the first group in the initial period had a high import value, while in later years the dynamics decreased in relation to other EU countries. An example of this was Greece, which was particularly affected by the economic crisis of 2010-2012. As a result, Greece purchased less expensive lamb meat. Demand also fell in Belgium and France, which resulted in a reduction in imports. The group of countries with average dynamics of lamb meat import included, among others, the United Kingdom 
and Italy, which are among the largest importers of this meat, as well as being producers in the EU. The stable value of imports in these countries may also reflect the stability of demand. In the third group, the value of lamb imports was systematically increasing. There were many countries importing relatively little of this meat, such as Poland, the Czech Republic, Lithuania, Latvia and Estonia. Changing food preferences (moving away from traditional products towards healthier and more expensive food), the enrichment of society and, at the same time, low production in these countries meant that the needs of the domestic market were increasingly satisfied by imports. Based on these data, it can be concluded that in the majority of countries with a low value of lamb meat imports, a gradual increase was the norm.

Groups of countries categorised in terms of growth rate compared to the EU as a whole are shown in Figure 5. Indicators of the diversity between clusters in this case are: $\tau(\boldsymbol{P})=0.06988$ and $\rho^{*}(\boldsymbol{P})=0.10468$ respectively. In the period 2015-2017, the value of lamb meat imports in the EU increased nominally by $20.23 \%$ in relation to the initial period of 2003-2005. In the first group, imports were systematically decreasing. In the second group, the increase in the value of lamb meat imports in subsequent periods was at a similar level. In the third group, the dynamics of changes was relatively high. Imports have been systematically increased. especially recently. As a result, the share of the value of lamb imports in relation to all EU countries increased in 2003-2005 from $17.64 \%$, and to $31.14 \%$ in the period 2015-2017. The dynamics of changes in imports could be the result mainly of the growing demand for lamb meat in countries with the smallest purchases and smallest production of this meat out of all EU countries.

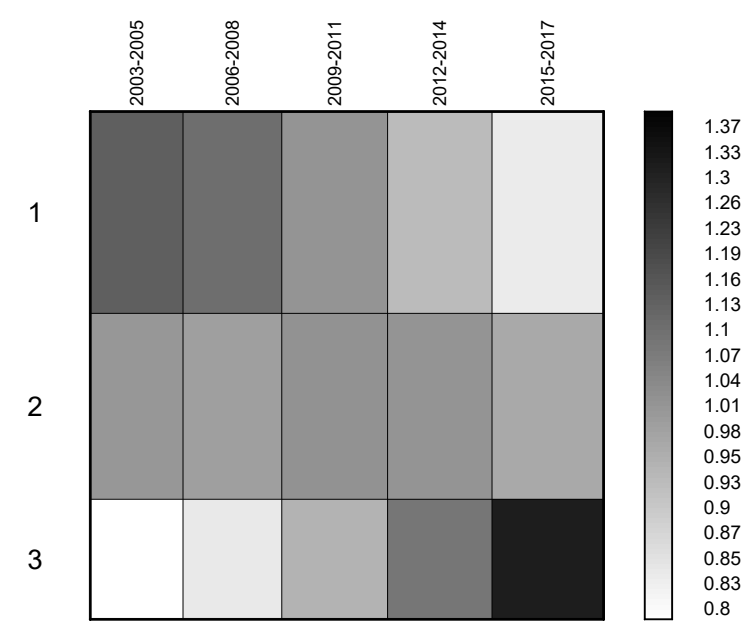

Fig. 5. "Overrepresentation map" of lamb meat import values in EU countries groups in 2003-2017

Source: authors' elaboration. 
Table 8 presents the composition of the three groups of countries clustered by the GCA algorithm, their ranking, and the values of the ar unlikeness measure, ordering them in terms of the growth rate of lamb imports in relation to the entire EU.

Table 8. Measures of ar unlikeness of EU countries in relation to the average

\begin{tabular}{|c|c|c|}
\hline \multicolumn{3}{|c|}{ Group 1 } \\
\hline $\mathrm{R}$ & Country & ar \\
\hline 1 & GR & -0.1678 \\
\hline 2 & BE & -0.0861 \\
\hline 3 & FR & -0.0453 \\
\hline
\end{tabular}

\begin{tabular}{|c|c|c|}
\hline \multicolumn{3}{|c|}{ Group 2} \\
\hline $\mathrm{R}$ & Country & ar \\
\hline 4 & ES & -0.0237 \\
\hline 5 & IT & -0.0200 \\
\hline 6 & HR & -0.0086 \\
\hline 7 & MT & -0.0022 \\
\hline 8 & GB & -0.0014 \\
\hline 9 & DK & 0.0079 \\
\hline 10 & PT & 0.0188 \\
\hline 11 & CY & 0.0356 \\
\hline 12 & LU & 0.0396 \\
\hline
\end{tabular}

\begin{tabular}{|c|c|c|}
\hline \multicolumn{3}{|c|}{ Group 3} \\
\hline $\mathrm{R}$ & Country & $a r$ \\
\hline 13 & DE & 0.0529 \\
\hline 14 & AT & 0.0814 \\
\hline 15 & HU & 0.0818 \\
\hline 16 & FI & 0.1183 \\
\hline 17 & CZ & 0.1192 \\
\hline 18 & RO & 0.1657 \\
\hline 19 & IE & 0.1705 \\
\hline 20 & SE & 0.1764 \\
\hline 21 & NL & 0.2094 \\
\hline 22 & LV & 0.2619 \\
\hline 23 & EE & 0.2753 \\
\hline 24 & SK & 0.3403 \\
\hline 25 & BG & 0.3751 \\
\hline 26 & PL & 0.3769 \\
\hline 27 & LT & 0.3932 \\
\hline 28 & SI & 0.4615 \\
\hline
\end{tabular}

Source: authors' results on the basis of GradeStat software.

There was concern that the results of the value of lamb meat imports in the long run may be associated with a change in the price of this type of meat. According to Anderson (2010), good measures of trade in agricultural products are not only value (e.g. in euros) but also in commodity mass (in tons). Using this method, trade turnovers could be correctly compared. Units of mass are used in biophysical accounting methods, and monetary measures in economic models of food supply chains [Weinzettel et al. 2013]. Therefore it was decided to perform an analysis using the same method for the volume of lamb meat imports in tons. It turned out 
that the correlation coefficient (Spearman's rank correlation coefficient in this case) was very high and equal to 0.97 , which allows for the conclusion that price changes did not have a significant impact on the results of the ranking based on the value of imports. The importance of relative prices and domestic income in the import of agri-food products has already been studied for France, Italy, the Netherlands and the United States [Tsionas, Christopoulos 2004]. Gotkolga [2006] showed, on a study of Turkey, that the value of meat imports depended on the demand for meat products, and was independent of the value of GDP per capita or real meat prices. The low price flexibility of the demand for imported food products, including meat, was confirmed by Shevchuk [2014] on a study on Ukraine and by Koo et al. [1994] for the USA. Meat is a product for which regularities are different to other food products in general.

The global foreign trade of food products is becoming more and more important. This is also confirmed by the allocation of about $20 \%$ of arable land and agricultural land for the production of agricultural products to sell abroad [Hoekstra, Mekonnen 2012; Porkka et al. 2013], including about 8\% for the production of exported animal products [MacDonald et al. 2015]. The importance of the EU in the global trade of agri-food products results from the fact that the bloc was the largest exporter and importer of this type of goods in the world. Both directions of exchange were significant. As regards exports, unprocessed products accounted for around 50\% of the value of all food commodities, while for imports this was up to $80 \%$. This pattern of trade has been prevalent in the EU in the last ten years. Imports were more geographically concentrated than exports and mainly concerned highly standardised wholesale products. Meat is one of the most important imported food products, with lamb being imported due to its shortage across the EU market [Agri-Food... 2018].

According to forecasts, the consumption of sheep and goat meat in the world will grow from an average $2 \mathrm{~kg}$ in 2015 to $2.4 \mathrm{~kg}$ per person in 2030. Greatest growth can be expected in developing countries with low meat consumption. At the same time, the real prices of lamb meat will grow compared to, for example, poultry meat [Livestock... 2018]. The presented factors. however. may affect the various dynamics of lamb meat imports in individual EU countries. Grade data analysis so far has been used in many studies, including the analyses of household budgets [Sutherland et al. 2002] and in medicine [Grzegorek 2007]. This method has rarely been used in the analysis of the dynamics of economic phenomena.

\section{Conclusion}

On the basis on the authors' analysis, especially with the use of GDA methods, EU countries were divided into groups characterised by smaller, medium and higher dynamics of changes in lamb imports. The most dynamic growth in imports 
of this type of meat is found among the newest EU member states. The obtained results allows on the following detailed conclusions:

1. Grade data analysis has pointed to large disparities between EU countries regarding changes in the value of lamb meat imports. In a small group of countries, the growth rate of lamb imports has decreased. These were significant importers, such as France and Belgium. The largest decrease was recorded in Greece, which may be related to its economic crisis. In a large group of countries there were no major changes in import dynamics. This group included, among others, the United Kingdom and Italy, both among the largest producers and importers of lamb meat. The most numerous group included countries where the value of lamb meat imports has increased. These were mostly countries importing relatively small amounts of this meat (with the exception of Denmark and the Netherlands, which are major importers), with low local production, and where the domestic market needs were increasingly satisfied by imports. Thus it can be concluded that in the majority of countries with a low value of lamb meat imports, these ones gradually increased. In addition, the production volume and the quantity of lamb meat imports were not related to the dynamics of changes in imports of this type of meat.

2. The analysis of clusters demonstrated that significant increase in the value of lamb imports occurred in the third group. This is evidenced by the shape of the overrepresentation map in Figure 5 (white colour indicating strong underrepresentation in the period 2003-2005, and black indicating strong overrepresentation in the period 2015-2017). There was also some stabilisation in the import of lamb meat among the largest importers of lamb. Increased lamb imports are associated with greater demand for this less popular type of meat. This phenomenon can be explained by the higher earnings of citizens of new EU Member States, increased access to products other than those considered as traditional, as well as the increase in migration levels that bring changes in the choice of food products. The hypothesis that the highest increase in the value of lamb meat imports occurred mainly in those EU countries where imports value was at a fairly low level was confirmed. This is in line with the theory of the convergence of dietary preferences in EU countries. The import of lamb was concentrated in France, the United Kingdom, Germany, Belgium, Spain and Italy. The conducted research confirms that grade data analysis can be a useful tool for analysing foreign trade indicators.

3. Meat, including lamb, is subject to different regularities than other food products. The analysis of the literature shows that the best indicators of the trade of agricultural products are trade value and freight weight. The results of this study confirm that lamb prices do not have that much influence on the dynamics of changes in the value of its imports.

4. It is expected that the import of lamb meat in the EU will continue to be on the increase. This is evidenced by forecasts for the consumption and production of 
this type of meat. Its consumption is expected to grow in countries with the lowest levels of consumption due to the growing popularity in markets that have been previously untapped.

\section{Bibliography}

Agri-Food Trade in 2014: EU-US Interaction Strengthened, 2015, Monitoring Agri-trade Policy MAP 2015-1, European Union.

Alexandratos N., Bruinsma J., 2012, World Agriculture Towards 2030/2050: The 2012 Revision (No. 12-03), ESA Working paper, Rome, FAO.

Anderson K., 2010, Globalization's effects on world agricultural trade, 1960-2050, Philosophical Transactions of the Royal Society B, vol. 365, pp. 3007-3021.

Atkinson A.B., 1970, On the measurement of inequality, Journal of Economic Theory, no. 2, pp. 244-263.

EU Agricultural Outlook for the Agricultural Markets and Income 2017-2030, 2017, Report of European Commission (18/12/2017). Pobrano z: https://ec.europa.eu/info/food-farming-fisheries/ farming/facts-and-figures/markets/outlook/medium-term_en.

Foley J.A., Ramankutty N., Brauman K.A., Cassidy E.S., Gerber J.S., Johnston M., Mueller N.D., O'Connell C., Ray D.K., West P.C., Balzer C., Bennett E.M., Carpenter S.R., Hill J., Monfreda C., Polasky S., Rockstrom J., Sheehan J., Siebert S., Tilman D., Zaks D.P.M., 2011, Solutions for a cultivated planet, Nature, 478, pp. 337-342.

Gastwirth J.L., 1972, The estimation of the Lorenz curve and Gini index, The Review of Economics and Statistics, vol. 54, no. 3, pp. 306-316

Goktolga Z.G., 2006, An analysis of import demand for meat and meat product in Turkey, Journal of Agronomy, 5(1), pp. 98-100.

Grzegorek M., 2007, Homogeneity of pixel neighborhoods in gray level images investigated by the Grade Correspondence Analysis, Computer Recognition Systems, 2, pp. 76-83.

Herrero M., Thornton P.K., Gerber P., Reid R.S., 2009, Livestock, livelihoods and the environment: Understanding the trade-offs, Current Opinion in Environmental Sustainability, vol. 1, no. 2, pp. 111-120.

Hoekstra A.Y., Mekonnen M.M., 2012, The water footprint of humanity, Proceedings of the National Academy of Sciences, vol. 109, pp. 3232-3237.

Koo W.W., Karemera D., Taylor R., 1994, A gravity model analysis of meat trade policies, Agricultural Economics, 10(1), pp. 81-88.

Livestock Commodities. Past and Present, 2018, http://www.fao.org/docrep/005/y4252e/y4252e05b.htm\# TopOfPage (23.11.2018).

MacDonald G.K., Brauman K.A., Sun S., Carlson K.M., Cassidy E.S., Gerber J.S., West P.C., 2015, Rethinking agricultural trade relationships in an era of globalization, BioScience, vol. 65, no. 3 , pp. 275-289.

Meat Production Statistics, 2018, Eurostat Statistics Explained, https://ec.europa.eu/eurostat/ statistics-explained/index.php/Meat_production_statistics (23.11.2018).

Porkka M., Kummu M., Siebert S., Varis O., 2013, From food insufficiency towards trade dependency: A historical analysis of global food availability, PLoS ONE, 8(12), e82714.

Ritchie H., Roser M., 2018, Meat and Seafood Production \& Consumption. Our World in Data, retrieved from: https://ourworldindata.org (23.11.2018).

Rokicki T., 2017, Food security in the European Union - the case study of the lamb market, Economic Science for Rural Development. Integrated and Sustainable Regional Development: 
Marketing and Sustainable Consumption: proceedings of the International Scientific Conference, ed. A. Auzina, 27-28 April 2017, Jelgava, no. 45, pp. 344-350.

Rokicki T., Ratajczak M., 2018, Segmentation of the EU countries in terms of the sheep production, Proceedings of the 2018 International Conference Economic Science for Rural Development, Jelgava, LLU ESAF, no. 48, pp. 229-236.

Shevchuk V., 2014, Modelling of agricultural import demand in Ukraine, Information Systems in Management, 3(3), pp. 201-211.

Sutherland H., Taylor R., Gomulka J., 2002, Combining household income and expenditure data in policy simulations, Review of Income and Wealth, 48(4), pp. 517-536.

Tsionas E., Christopoulos D., 2004, International evidence on import demand, Empirica, vol. 31, no. 1, pp. 43-53.

Toth G., 2015, Mean Minkowski Measures. In: Measures of Symmetry for Convex Sets and Stability, Universitext. Springer, Cham, doi: https://doi.org/10.1007/978-3-319-23733-6_4.

Vepstas L., 2008, On the Minkowski Measure. Pobrano z: arXiv preprint arXiv:0810.1265.

Weinzettel J., Hertwich E.G., Peters G.P., Steen-Olsen K., Galli A., 2013, Affluence drives the global displacement of land use, Global Environmental Change, vol. 23, pp. 433-438.

\section{ZRÓŻNICOWANIE IMPORTU MIĘSA JAGNIĘCEGO W KRAJACH UE I TENDENCJE JEGO ZMIAN}

Streszczenie: W pracy dokonano próby porównania krajów Unii Europejskiej pod względem dynamiki zmian wartości importu mięsa jagnięcego w latach 2003-2017. Wzorcem, względem którego dokonano tego porównania, była wartość średnia, którą należy tu rozumieć jako dynamikę wzrostu badanej cechy dla wszystkich krajów Unii łącznie. W tym celu posłużono się narzędziami związanymi z tzw. gradacyjną analizą danych, takimi jak wskaźnik niepodobieństwa struktur ar (służacy w tym wypadku do określenia zarówno kierunku zmian. jak i szybkości tych zmian na tle całej UE), oraz mapami nadreprezentacji (służącymi wizualizacji tych zmian oraz ich interpretacji). Dodatkowo za pomocą metod GCA podzielono kraje UE na grupy charakteryzujące się mniejszą. średnią i wyższą dynamiką zmian importu jagnięciny. Okazuje się. że nabardziej dynamiczny wzrost importu tego rodzaju mięsa dotyczył krajów o stosunkowo niskim stażu członkowskim w UE. Może to świadczyć o zmiananch preferencji żywieniowych w tych krajach. Ma to związek z większą dostępnością dóbr uważanych dotychczas za luksusowe, większą świadomością, jeżeli chodzi o tzw. zdrową żywność, i oczywiście z bogaceniem się społeczeństw żyjących w państwach, które do Unii dołączyły.

Slowa kluczowe: import mięsa owczego, dynamika wzrostu, jagnięcina, gradacyjna analiza danych, mapy nadreprezentacji. 